\title{
Elections in the Divisions
}

\section{QE Division}

The new Board of the Quantum Electronics Division, following the recommendations of the outgoing Board is constituted as follows:

B. Bölger, Philips' Research Laboratories, Eindhoven

D.S. Chemla, CNET, Bagneux

R. Dändliker, University, Neuchâtel

C. Flytzanis, Ecole Polytechnique, Palaiseau

K.L. Kompa, Max-Planck Inst., Garching

V.S. Letokhov, Institute of Spectroscopy, Moscow

T.S. Moss, RSRE, Gt. Malvern

R. Pratesi, Quantum Electronics Lab., Florence

C.A. Sacchi, Institute of Physics, Milan

W. Schmidt, Carl Zeiss, Oberkochen

S.D. Smith, University, Edinburgh

S. Stenholm, University, Helsinki

H.P. Weber, University, Bern

B. Wilhelmi, University, Jena

The new Chairman and Secretary will be elected at the meeting of the Board in October.

\section{University of Geneva}

A post doctoral appointment is available at the Department of $\mathrm{Nu}$ clear Physics for a young physicist with some experience in high energy physics.

The candidate would join one of the research groups of the department at CERN. The appointment is limited to five years.

Applicants should submit resume and list of publications to the:

Directeur du Départment de Physique Nucléaire et Corpusculaire,

Ecole de Physique,

1211 Geneva 4

\section{Call for Nominations for CMD Sections}

Elections to the Committees responsible for the Sections of the Condensed Matter Division will be held in November/ December by mail.

Below is a provisional list of candidates prepared by the Chairman of the Division in consultation with the present Committee Chairmen.

Individual Ordinary Members who are Section members and National Societies (Category 4B), are invited to make additional nominations. Those made by I.O.M.s should be supported by at least six members.

The Committees consist of six full members, elected for a term of three years, plus up to six co-opted members. The Sections then elect their own Chairmen and these serve on the Board of the Division.

In the lists that follow, the names of the Committee members elected in 1977 are marked with an asterisk.

\section{Low Temperature Section}

G. Deutscher, Tel-Aviv

*) G. Eilenberger, Jülich

M. Krusius, Turku

H. Postma, Delft

L. Rinderer, Lausanne

*) C. Rizzuto, Genoa

L. Smrcka, Prague

D. Thoulouze, Grenoble

W.F. Vinen, Birmingham

\section{Macromolecular Section}

G. Bodor, Budapest

*) H.H. Kausch, Lausanne

A. Keller, Bristol

*) J.P. Mercier, Louvain-la-Neuve

L. Monnerie, Paris

*) G. Zerbi, Trieste

\section{Magnetism Section}

L.J. de Jongh, Leiden

*) P. Erdös, Lausanne

*) A. Hubert, Erlangen

G.M. Kalvius, Munich

*) V. Kambersky, Prague

\section{Metals Section}

D. Buschow, Eindhoven

*) G. Caglioti, Milan

*) R.M.J. Cotterill, Lingby

*) D.J. Fabian, Glasgow

O. Fischer, Geneva

J.P. Gaspard, Liege

G. Saada, Saint Denis

Semiconductors and Insulators Section

${ }^{*}$ ) F.W. Ainger, Towcester

D. Bäuerle, Linz

F. Beleznay, Erlangen

R. Blinc, Ljubljana

Surfaces and Interfaces Section

G. Benedek, Milan

A. Cassuto, Villers-les-Nancy

*) G. Ertl, Munich

*) B. Feuerbacher, Noordwyjk B.I. Lundqvist, Gothenburg

*) A. van Oostrom, Eindhoven R.F. Willis, Cambridge

Nominations should arrive at the EPS Secretariat by 14 November at the latest.

Preliminary registrations for the 5th EPS General Conference at Istanbul, 7-11 September, 1981 now total over 400. Other potential participants who have not yet returned the (blue) form indicating which Symposia interest them particularly are asked to inform the EPS Secretariat as soon as possible to help in determing space allocations.

Orders for European Journal of Physics from Individual Ordinary Members and from members of EPS $\mathrm{Na}$ tional Societies may be sent to the EPS Secretariat. Annual subscription is $40 \mathrm{Sw} . \mathrm{Fr}$. Libraries should place their orders directly with the Institute of Physics in the UK (subscription f25.00/an.).
EPS Divisions, Sections and Group Astronomy and Astrophysics Division Solar Section

Atomic Physics Division

Atomic Spectroscopy Section

Chemical Physics

Electronic and Atomic Collisions

Molecular Physics

Computational Physics Group

Condensed Matter Division

Low Temperature Section

Macromolecular Physics

Magnetism

Metals

Semiconductors and Insulators

Surfaces and Interfaces

High Energy \& Particle Physics Division

Nuclear Physics Division

Plasma Physics Division

Quantum Electronics Division
Europhysics News is the official journal of the European Physical Society that comprises 28 National Societies, Academies and Groups, over 3000 Individual Ordinary Members and 30 Associate Members. Governing bodies of EPS are the General Meeting, Council and an elected Executive Committee responsible for detailed policy. Executive Committee responsible for detailed policy Europe and encourages all aspects of international exchange in physics. EPS awards scholarships for research and studies in different countries. EPS research and studies in different countries. EPS
publishes, in addition to Europhysics News, publishes, in addition to Europhysics News,
Europhysics Conference Abstracts, Europhysics Educa tion News and the Proceedings of its General Con ferences. Individual Ordinary Members receive Europhysics News (subscription for non-members: 75 Europhysics News (subscription for non-members: 75 and pay reduced fees at conferences. Application for membership is made through the permanent Secretariat in Geneva. Annual subscription for members of a $\mathrm{Na}$ tional Society from 1 January, 1980 is $32 \mathrm{Sw} . \mathrm{Fr}$.

\section{Editor: E.N. Shaw}

Meetings Compilation: W.S. Newman

Editorial Board

K. Appert, A. Baratoff, G.J. Béné

G.R. Macleod, A. Maeder, J. Mulle

Editorial and Advertising Office at the EPS Secretariat.

AddresS: EUROPEAN PHYSICAL SOCIETY P.O. Box 69 , CH-1213 Petit-Lancy 2 Switzerland

Telephone: Geneva (22) 931130

Telex: 23455 alarm ch

Cables: europhys genève

Printed by: Pfirter frères SA CH-1213 Petit-Lancy/Switzerland 